\title{
Determinants of neurological syndromes caused by varicella zoster virus (VZV)
}

\author{
Peter GE Kennedy ${ }^{1} \cdot$ Trine H Mogensen ${ }^{2,3}$
}

Received: 18 February 2020 / Revised: 24 April 2020 / Accepted: 14 May 2020 / Published online: 3 June 2020

(C) The Author(s) 2020

\begin{abstract}
Varicella zoster virus (VZV) is a pathogenic human herpes virus which causes varicella as a primary infection, following which it becomes latent in peripheral autonomic, sensory, and cranial nerve ganglionic neurons from where it may reactivate after decades to cause herpes zoster. VZV reactivation may also cause a wide spectrum of neurological syndromes, in particular, acute encephalitis and vasculopathy. While there is potentially a large number of coding viral mutations that might predispose certain individuals to VZV infections, in practice, a variety of host factors are the main determinants of VZV infection, both disseminated and specifically affecting the nervous system. Host factors include increasing age with diminished cell-mediated immunity to VZV, several primary immunodeficiency syndromes, secondary immunodeficiency syndromes, and drug-induced immunosuppression. In some cases, the molecular immunological basis underlying the increased risk of VZV infections has been defined, in particular, the role of POL III mutations, but in other cases, the mechanisms have yet to be determined. The role of immunization in immunosuppressed individuals as well as its possible efficacy in preventing both generalized and CNS-specific infections will require further investigation to clarify in such patients.
\end{abstract}

Keywords Varicella zoster virus · Nervous system · Varicella $\cdot$ Herpes zoster $\cdot$ Encephalitis $\cdot$ POL III $\cdot$ Host genetics · Immunodeficiency

$\begin{array}{ll}\text { Abbreviations } \\ \text { ADA } & \text { Adenosine deaminase } \\ \text { CARD11 } & \text { Caspase recruitment domain containing protein } \\ \text { CARMIL2 } & \text { Capping protein Arp2/3, myosin linker-I linker } \\ \text { cGAS } & \text { Cyclic GMP-AMP synthase } \\ \text { CMV } & \text { Cytomegalovirus } \\ \text { CSF } & \text { Cerebrospinal fluid } \\ \text { CTLA-4 } & \text { Cytotoxic T lymphocyte-associated antigen } 4 \\ \text { CXCR4 } & \text { C-X-C Chemokine receptor type } 4 \\ \text { DOCK } & \text { Dedicator of cytokinesis } \\ \text { GINS1 } & \text { Go-ichi-ni-san } \\ \text { HAART } & \text { Highly active anti-retroviral treatment }\end{array}$

Peter GE Kennedy

Peter.Kennedy@glasgow.ac.uk

1 Institute of Infection, Immunity and Inflammation, College of Medical, Veterinary and Life Sciences, University of Glasgow, Glasgow, Scotland, UK

2 Departments of Infectious Diseases and Clinical Medicine, Aarhus University Hospital, Aarhus, Denmark

3 Department of Biomedicine, Aarhus University, Aarhus, Denmark
HLH Hemophagocytic lymphohistiocytosis

HSV Herpes simplex virus

IFN Interferon

IL7R Interleukin 7 receptor

IL2RG Interleukin 2 receptor gamma

IRIS Immune reconstitution inflammatory syndrome

JAK Janus kinase

MAGT1 Magnesium transporter 1

MCM4 Minichromosome maintenance complex component 4

MS Multiple sclerosis

NK Natural killer

PHN Post herpetic neuralgia

PID Primary immunodeficiency

PML Progressive multifocal leukoencephalopathy

POL III RNA polymerase III

PRR Pattern recognition receptor

SCID Severe combined immunodeficiency

STIM1 Stromal interacting molecule 1

STING Stimulator of interferon genes

STAT Signal transducer and activator of transcription

STK4 Serine/threonine protein kinase 4 
TYK Tyrosine kinase

VZV Varicella zoster virus

\section{Introduction}

Varicella zoster virus (VZV) is a pathogenic and ubiquitous human alpha herpes virus which causes varicella (chickenpox) as a primary infection, usually, though not always, in children following which it may become latent in neurons in peripheral autonomic, sensory, and cranial nerve ganglionic neurons along the entire human neuroaxis (Kennedy et al. 1998; Gershon et al. 2015). After decades, either spontaneously or following various triggering factors, VZV may reactivate to cause herpes zoster (shingles) which is a painful vesicular skin eruption in the distribution of a particular dermatome (Nagel and Gilden 2007). Both varicella and herpes zoster may be more frequent and serious in individuals who are immunosuppressed either from diseases disrupting the immune system or because of drug therapy for cancer or various autoimmune conditions (Fig. 1). A variety of neurological conditions may follow both varicella and herpes zoster, and the key determinants for these are now being determined. There is no doubt that host immune factors are of primary importance in the development of these complications, but it also seems reasonable to assume that both viral and host factors may play a role and could also interact.

In this review of the subject, we first provide a brief overview of the neurological syndromes associated with varicella and zoster and then consider the potential viral and host determinants for neurological disease development, focussing on recent evidence implicating the key role of host genetic mutations in increasing susceptibility to VZV-induced nervous system disease.

\section{Overview of neurological syndromes associated with primary and reactivated VZV}

The neurological complications of both varicella and zoster have been described in considerable detail elsewhere (Gershon et al. 2015; Kennedy and Gershon 2018) and will be briefly outlined here. Though varicella is usually an uncomplicated but unpleasant exanthema with a pruritic vesicular rash, it can be a very serious illness in children who are immunocompromised due to illness or drug therapy as well as in the few adults who contract the illness (Kennedy and Gershon 2018). While superadded bacterial infection of the

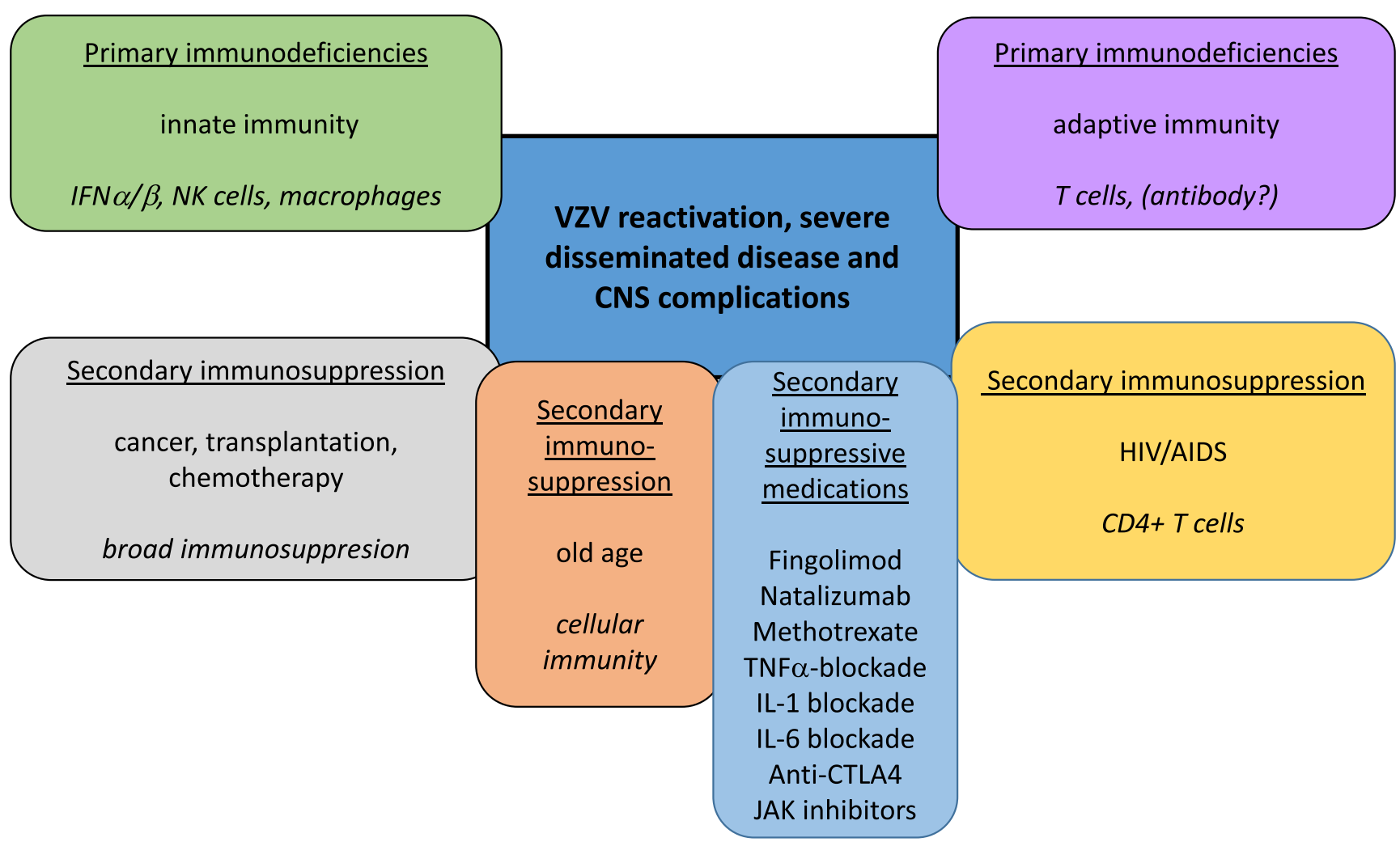

Fig. 1 Host factors predisposing to VZV reactivation, severe disseminated disease, and CNS complications. Predisposing factors include primary genetically determined immunodeficiencies in innate or adaptive immunity as well as states of secondary immunodeficiency imparted by cancer, transplantation, chemotherapy, HIV/AIDS, immunosuppressive medications for various autoimmune conditions, age-related immune decline, and others 
skin, septicaemia, and pneumonia may complicate varicella, the most frequent neurological complication of varicella is encephalitis which refers to severe inflammation of the brain parenchyma (Chaudhuri and Kennedy 2002). This is a rare complication, probably occurring in less than $0.1 \%$ of cases though encephalitis itself accounts for about $90 \%$ of neurological complications (Kennedy 1987). In some cases, there is a syndrome of acute cerebellar ataxia due to a postinfectious meningoencephalitis that is typical of VZV (Chaudhuri and Kennedy 2002) and accounts for about $50 \%$ of all the neurological complications (Kennedy 1987). Much rarer neurological syndromes have also been described in the literature and include myelitis, Reye's syndrome, congenital varicella syndrome and, very rarely, the Guillain-Barre syndrome (Johnson and Milbourn 1970; Kennedy 1987).

The neurological features of VZV reactivation, usually manifest as herpes zoster, are protean and the observed range of these manifestations is progressively increasing as the viral detection methods for VZV in human tissues become more advanced and rigorously applied in inflammatory nervous system conditions of uncertain cause (Nagel and Gilden 2007). Of all the various complications of zoster, post herpetic neuralgia (PHN) is the most recognized. Both zoster and PHN are increasingly common in the elderly and also the immunosuppressed, probably because of diminished cell-mediated immunity to the virus (Hope-Simpson 1965; Gershon et al. 2015). While zoster produces a painful pruritic dermatomally distributed rash, PHN occurs when the severe dermatomal pain persists after 3 months following healing of the zoster rash (Kennedy et al. 2013). PHN occurs in about $40 \%$ of zoster patients over 60 years (Gilden et al. 2000) and is extremely refractory to treatment, and most of which are usually ineffective in relieving the persistent pain. The cause of PHN is not understood though both host and viral factors may be involved (Kennedy et al. 2013; Gershon et al. 2015). Reported risk factors for the development of PHN are an age of more than 50 years, female gender, a zoster viremia detectable by the polymerase chain reaction (PCR) (which currently remains somewhat uncertain), severe or disseminated rash, and the presence of a prodrome and severe pain at the time of its presentation (Wareham and Breuer 2007).

Herpes zoster can rarely be followed by a meningoencephalitis which may run a relatively benign course, and in about $0.25 \%$ of zoster cases, an encephalomyelitis may occur (Kennedy 1987). While there is some controversy as to whether this is a separate disease entity from a vasculitis (see below), the authors consider these two conditions as separate. The factors that may increase the duration of this condition include immunosuppression, disseminated zoster lesions, and the presence of extracranial signs (Jemsek et al. 1983).

A VZV-induced vasculopathy is now well characterized and is one of the most important complications of zoster. The spectrum of this vasculopathy has been extended considerably and includes temporal artery involvement (see below), ischemic and hemorrhagic stroke, arterial dissection, transient ischemic attacks, ischemic cranial neuropathies, spinal cord infarction, and cerebral venous thrombosis (Nagel and Gilden 2014; Kennedy 2016). Confusion, seizures, a variety of focal neurological signs, and progressive cognitive decline are typical clinical features of a VZV vasculopathy, and the diagnosis of which may be established by analysis of the cerebrospinal fluid (CSF) and arteriography or MRI angiography (Gilden et al. 2000; Kennedy 2016). Interestingly, the presence and level of anti-VZV IgG antibody in the CSF has been shown to be even more sensitive in diagnosing a VZV vasculopathy than PCR which detects VZV DNA (Nagel et al. 2007). It should be appreciated, however, that there is some uncertainty as to the actual specificity of the CSF antibody/ serum antibody ratio as used in some studies for the diagnosis of VZV-related disease. Treatment has been formulated on a relatively small number of cases but usually consists of a 14day course of intravenous acyclovir and a short 5-7-day course of oral corticosteroids (Kennedy 2016). As is the case for many of the VZV-associated neurological syndromes, however, there is just not enough clinical data available to be certain of the optimal therapeutic regime.

Segmental motor weakness affecting the limbs, intercostal or diaphragmatic muscles may occur in association with zoster infection, and the region of the weakness does not necessarily correlate with the distribution of the zosteriform rash (Kennedy 1987). The prognosis is thought to be generally good. In addition, zoster may also cause a myelitis with characteristic clinical features. Magnetic resonance imaging (MRI) of the relevant region of the spinal cord may help confirm the diagnosis.

It is now recognized that zoster can occur in the absence of the typical rash and this has been termed zoster sine herpete (ZSH) (Gilden et al. 1994). The spectrum of neurological syndromes that have now been described in ZSH has steadily increased to the extent that this diagnosis should be considered in any patient who presents with a presentation of acute, subacute, or chronic brain or spinal cord disease of unknown cause, together with a CSF pleocytosis (Nagel and Gilden 2007, Kennedy 2011). The diagnosis, once suspected, can be established using PCR to detect VZV DNA in the CSF or else serologically by the presence of anti-VZV IgG in the CSF.

Although VZV has been reported to be the likely cause of a high proportion of cases of giant cell arteritis (GCA), this finding remains controversial and is the subject of ongoing investigation. Thus, Gilden et al. (2015) first reported that three quarters of temporal arteries (TAs) from patients who had positive inflammatory pathology contained VZV antigen, mainly in so-called skip regions, and this contrasted with normal TAs of which only $8 \%$ contained VZV antigen. Their subsequent study reported that VZV antigen was also present 
in $64 \%$ of TAs that were from patients with suspected GCA but who had negative biopsy pathology as compared with only $22 \%$ of normal TAs (Nagel et al. 2015). It is possible that there exists a subset of GCA patients in whom VZV may be playing a causative role, a notion that has clear therapeutic implications, but these findings have not been replicated (Kennedy et al. 2003, Buckingham et al (2018), Ostrowski et al. 2019). Further studies of this phenomenon are ongoing, and the results of which are awaited with interest.

Since zoster frequently affects the first division of the trigeminal nerve, VZV may also cause various types of eye disease, both neurological and primarily ophthalmological. Thus, zoster may cause oculomotor nerve and optic nerve lesions (Kennedy 1987) as well as such local conditions as a keratitis, acute retinal necrosis, a characteristic progressive outer retinal necrosis, retinal hemorrhages, and macular lesions (Gershon et al. 2015). Further, the ability of zoster to cause cranial neuropathies includes a seventh (facial) nerve palsy in association with geniculate zoster, the Ramsay Hunt syndrome, a painful condition that requires treatment with antiviral drugs (Kennedy 2016). In fact, most herpes zoster in adults probably warrants treatment with antiviral drugs.

Finally, very rare cases have been described, in which VZV encephalitis triggers autoimmune NMDA receptor immunoreactivity/encephalitis, possibly through molecular mimicry or "altered self" or as a paraneoplastic phenomenon (Schabitz et al. 2014), although this is more prominent post herpes simplex encephalitis (Armangue et al. 2015).

\section{Possible viral determinants of neurological disease}

Although host factors are probably predominant in determining susceptibility to VZV and its complications, it is still possible that certain viral factors may also play a role in this process. In this context, a critical factor is clearly the number and nature of any coding mutations that may occur in the normal VZV genome. While in theory, any of the $\sim 125,000$ bases in VZV could mutate and produce viable virus, and in practice, it is more relevant that there may be as many as 300 single nucleotide polymorphisms (SNPs) when comparing two VZV from different geographic clades (D.Depledge personal communication). Whether any detected SNPs confer important functionality in the VZV is certainly possible though not yet known for certain. But these possibilities do provide a feasible background for different VZV strains producing different clinical phenotypes in its human host. Support for this notion is suggested by finding mutations in the vaccine strain VZV that are more likely to cause complications of vaccination.

It is possible that a particularly virulent strain of VZV may exert a clinically significant phenotype, and a recent study provided evidence that this may well be the case. When 11 VZV isolates from patients who had developed PHN were compared with $9 \mathrm{VZV}$ isolates from non-PHN patients for their ability to produce different electrophysiological effects in the ND7/23-Nav1.8 neuroblastoma cell line, it was found that the PHN-associated viruses significantly increased sodium current amplitude in the cell line when compared with non-PHN VZV, wild-type (Dumas), or vaccine VZV strains (Kennedy et al. 2013). These PHN-associated VZV sodium current increases were found to be mediated in part by the Nav 1.6 and Nav 1.7 sodium ion channels. While extrapolation of such in vitro findings to the human scenario should be viewed with some caution, nevertheless this does suggest a possible mechanism of virally induced pain since alterations of sodium channel currents are known to be associated with the sensation of pain (Wood et al. 2004; Garry et al. 2005). In order to gain a greater understanding of the possible role of the virus in determining the various neurological syndromes, it will be important to confirm and extend this type of study and to analyze potential coding mutations in the VZV genome in further detail. Also, it is entirely reasonable to assume that both host and viral factors may interact to influence the development of the various VZV clinical syndromes.

\section{Host factors that determine susceptibility to VZV-associated neurological disease}

\section{Primary immunodeficiencies predisposing to severe Varicella, Zoster and VZV CNS infection}

The precise immunological correlates of protective immunity to VZV remain incompletely understood. This is partly because VZV is a strict human pathogen and only limited in vivo data from (humanized) mouse models or postmortem examination of human trigeminal ganglia are available. In this context, the study of human inborn errors of immunity conferring increased susceptibility to VZV has proven particularly valuable. It is clear that a prominent role is played by cellular immunity exerted by $\mathrm{T}$ cells and natural killer (NK) cells (Duncan and Hambleton 2015; Gershon et al. 2015; Zerboni et al. 2014). The picture is less clear in the case of the role of humoral immunity, and antibodies are generally not believed to contribute to a large extent, as also suggested by the absence of VZV infection as a prominent clinical phenomenon in human antibody deficiencies. All types of interferons (IFNs) serve important functions in restricting VZV replication and spread, particularly during the viremic phase and in the skin during varicella, and also possibly in maintaining latency in sensory neuronal ganglia (Carter-Timofte et al. 2018b; Duncan and Hambleton 2015) (Fig. 2). It is therefore relevant that recent studies demonstrated an antiviral role of both IFN $\alpha / \beta$ and IFN $\gamma$ in vitro (Sen et al. 2018). 

Primary infection
Latency
Reactivation

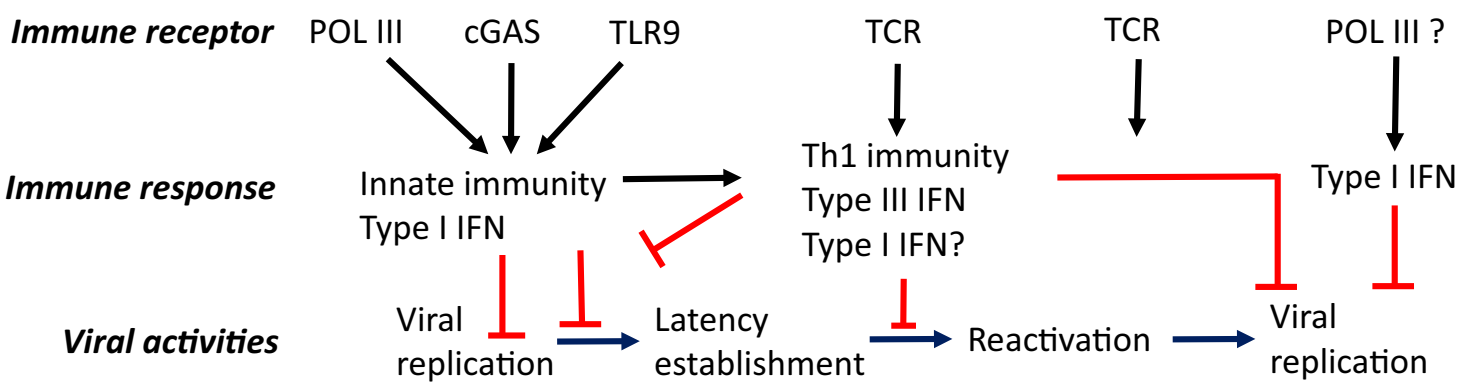

Fig. 2 Antiviral immune responses to VZV during different phases of infection. Roles for innate and adaptive immune receptors and responses in primary VZV infection, latency, and reactivation. Innate immune responses include recognition of VZV DNA by cytosolic DNA sensors POL III and cGAS, as well as by endosomal TLR9 to generate type I interferon $(\mathrm{IFN} \alpha / \beta)$ and prime adaptive immunity. NK cells also play a

Several primary immunodeficiencies (PIDs) have been shown to predispose to severe disseminated primary varicella, frequent and extensive zoster, varicella pneumonia, and in some cases CNS complications (for an overview, see Table 1). The classical example is severe combined immunodeficiency (SCID) with defects in T cells, B cells, and NK cells caused by defects in IL2RG, RAG1/2, ADA, JAK3, and IL7R genes, in which an increased risk of disseminated VZV infection has been well-recognized for many years (Arvin et al. 2010; Carter-Timofte et al. 2018b; Fischer et al. 2015; Zerboni et al. 2014). Other combined PIDs mainly affecting T cells, NK cells, and to a lesser extent B cells, including CORONIN1A (Yee et al. 2016), Wiskott Aldrich syndrome (Albert et al. 2011), CARMIL2 (Schober et al. 2017), MAGT1 (Ravell et al. 2020), STK4 (Abdollahpour et al. 2012), and CXCR4 (Heusinkveld et al. 2017) deficiencies, have also been associated with recurrent zoster and/or persistent skin infection (Al-Herz and Essa 2019). The central role exerted by $\mathrm{T}$ cells in anti-VZV immunity is further demonstrated by the occurrence of severe varicella, pneumonia, or chronic VZV infection described in conditions involving the $\mathrm{T}$ cell surface molecules CD27 (Alkhairy et al. 2015) and CD70 (Abolhassani et al. 2017) as well STIM1 (Picard et al. 2009). Recently, a defect in DNA polymerase deltal causing a combined immunodeficiency particularly affecting naïve $T$ cells was described in three children with recurrent infections, including one with encephalitis during primary varicella (Cui et al. 2020). Hemorrhagic varicella, zoster, and keratitis were documented in STAT5B deficiency (Bezrodnik et al. 2015) and DOCK2 deficiency affecting T cells and NK cells with impaired IFN $\alpha$ responses (Dobbs et al. 2015). Of particular interest is the description of a patient with vaccine strain VZVinduced CNS vasculopathy as the presenting feature of DOCK8 deficiency (Sabry et al. 2014; Zhang et al. 2009). role through cytotoxic activities. Later, adaptive immune responses mediated by $\mathrm{T}$ cells produce type II IFN (IFN $\gamma$ ) and other cytokines. A combination of cellular immunity and IFNs is suggested to be involved in maintaining latency and preventing viral replication and reactivation. POL III, RNA polymerase III, cGAS cytosolic GMP-AMP synthase, TLR, Toll-like receptor

Severe disseminated infection with herpesviruses, including VZV, herpes simplex virus (HSV), and cytomegalovirus (CMV), was originally described in a patient with NK cell deficiency, many years later realized to be caused by a genetic variant in the myeloid transcription factor GATA2 causing MonoMAC and also involving cytopenia in monocytic and $\mathrm{B}$ cell lineages in addition to NK cell deficiency (Biron et al. 1989; Hsu et al. 2011). Subsequently, reports have described the rare occurrence of hemophagocytic lymphohistiocytosis (HLH) during VZV infection in patients with this disease (Prader et al. 2018; Spinner et al. 2014) as well as in other PIDs distinctive from classical HLH genetic defects (Bode et al. 2012). Moreover, disseminated VZV infection has been observed in other states of impaired NK cell number or function, such as MCM4 (Gineau et al. 2012) and GINS1 deficiencies (Cottineau et al. 2017).

Finally, the group of PIDs that interfere with macrophage function and defense against intracellular pathogens may predispose to infection with mycobacteria and viruses and include defects in the IFN $\gamma$ receptor (IFN $\gamma \mathrm{R}$ ) (Roesler et al. 1999), STAT1 loss-of-function (LOF) (Dupuis et al. 2003), and the tyrosine kinase (TYK)2 (Kreins et al. 2015) downstream of IFN $\alpha / \beta$ and IFN $\gamma$ receptors.

More recently, the innate cytosolic DNA sensor POL III was added to the list of PIDs predisposing to VZV infection through the identification and characterization of an autosomal dominant inherited loss-of-function POL III defect in four otherwise healthy children with severe VZV in the CNS or lungs (Ogunjimi et al. 2017). RNA polymerase III is a 17subunit enzyme with dual functions in both promoter dependent transcription of tRNA and rRNA as well as in innate sensing of AT-rich DNA, converting this into 5'-phosphorylated single-stranded RNA, which serves as a ligand for the RNA sensor RIG-I (Ablasser et al. 2009; Chiu et al. 2009). 
Table 1 Primary immunodeficiencies associated with severe VZV infection and/or CNS complications

\begin{tabular}{|c|c|c|c|}
\hline $\mathrm{PID} /$ gene & Defective immune cells & Clinical presentation with VZV disease & References \\
\hline $\mathrm{SCID}^{\mathrm{a}}$ & $\mathrm{T}, \mathrm{B}$, and NK cells & Diss. infection & Fischer et al. (2015) \\
\hline CORO1A & $\mathrm{T}$ and $\mathrm{B}$ cells & Diss. infection, pneumonitis, meningitis & Yee et al. (2016) \\
\hline WAS & All leukocytes & Severe recurrent zoster & Albert et al. (2011) \\
\hline CARMIL2 & $\mathrm{T}$ and $\mathrm{B}$ cell & Recurrent varicella & Schober et al. (2017) \\
\hline MAGT1 & $\mathrm{T}$ and NK cells & Severe varicella, recurrent zoster & Ravell et al. (2020) \\
\hline STK4 & $\mathrm{T}$ and $\mathrm{B}$ cells & Recurrent severe zoster & Abdollahpour et al. (2012) \\
\hline CXCR4 & $\mathrm{T}$ and $\mathrm{B}$ cells, neutrophils & Recurrent zoster & Heusinkveld et al. (2017) \\
\hline $\mathrm{CD} 27$ & $\mathrm{~T}$ cells & Severe varicella & Alkhairy et al. (2015) \\
\hline $\mathrm{CD} 70$ & $\mathrm{~T}$ cells & Severe varicella & Abolhassani et al. (2017) \\
\hline STIM1 & $\mathrm{T}$ cells & Severe varicella, cellulitis & Picard et al. (2009) \\
\hline POL D1 & $\mathrm{T}$ cells & Severe recurrent varicella, encephalitis & Cui et al. (2020) \\
\hline STAT5B & $\mathrm{T}$ and NK cells & Hemorrhagic varicella, zoster, keratitis & Bezrodnik et al. (2015) \\
\hline DOCK2 & $\mathrm{T}$ and NK cells & Hemorrhagic varicella, pneumonitis & Dobbs et al. (2015) \\
\hline DOCK8 & $\mathrm{T}, \mathrm{B}$, and NK cells & Diss. VZV, CNS vasculopathy & Zhang et al. (2009); Sabry et al. (2014) \\
\hline GATA2 & Monocytes, NK, B cells & Diss. infection, HLH & Biron et al. (1989); Prader et al. (2018) \\
\hline MCM4 & NK cells & Severe varicella & Gineau et al. (2012) \\
\hline GINS1 & NK cells & Severe varicella & Cottineau et al. (2017) \\
\hline IFNGR & All cells & Varicella pneumonia, CNS infection & Roesler et al. (1999) \\
\hline STAT1 LOF & All cells & Diss. varicella & Dupuis et al. (2003) \\
\hline TYK2 & All cells & Recurrent zoster & Kreins et al. (2015) \\
\hline POL III (POLR3 A, C, F) & Leukocytes & Encephalitis, CNS vasculitis, pneumonia & $\begin{array}{l}\text { Ogunjimi et al. (2017); Carter-Timofte } \\
\text { et al. (2018a) }\end{array}$ \\
\hline
\end{tabular}

PID primary immunodeficiency; $L O F$ loss of function; $H L H$ hemophagocytic lymphohistiocytosis

${ }^{\text {a }}$ SCID genes: IL2RG, RAG1, RAG2, ADA, JAK3, IL7R

Previously described associations between POL III defects and human disease include the finding of mutations in POLR $3 A$ and POLR3B in the recessive $\mathrm{H} 4$ syndrome with severe hypomyelinating leukoencephalopathy (Bernard et al. 2011; Saitsu et al. 2011). The discovery of functional POL III deficiency suggests an important contribution of innate immunity to antiviral defenses against VZV through recognition of the AT-rich VZV genome and demonstrates a major role of type I IFN. A subsequent report described POLR $3 F$ mutations in monozygotic adult twins both experiencing repeated CNS vasculitis presenting in a stroke-like manner with hemiparesis, sensory deficits, and headache, and clinically diagnosed as recurrent VZV CNS reactivation (Carter-Timofte et al. 2018b). This study, together with another description of POL III defects in adults with VZV encephalitis, suggests that POL III may be important in protection against VZV CNS disease, not only during primary VZV infection but also during reactivation, and thus potentially play a role in controlling VZV latency, although the cellular and molecular correlates of this are not well understood at present (Carter-Timofte et al. 2018a, b, 2019). Whether immunodeficiencies predisposing to VZV encephalitis versus those predisposing to vasculitis are intrinsically different, remains to be studied in detail in larger studies. There is clearly a different pathogenesis between classical VZV meningoencephalitis and the presence of vasculitis developing in some cases of VZV CNS infection (Gilden et al. 2009). At the cellular level, increased viral replication, which for VZV is known to also include endothelial cells within the CNS, may evoke enhanced inflammatory responses secondary to the presence of the virus and thereby explain, at least in part, the development of vasculitis and immunopathology in these patients.

The precise mechanisms whereby POL III restricts VZV in an apparently relatively specific manner have not been fully elucidated. Remaining unanswered questions include (i) issues related to its cell type specificity and redundancy, (ii) the specificity of POL III defects in VZV infection, (iii) its role in primary infection (primarily children) versus reactivation (primarily adults), (iv) its function in innate sensing versus priming of adaptive immunity, and (v) whether Pol III exerts its antiviral role by one (i.e., innate VZV sensing) or whether several different mechanisms may be involved and in which cellular context. 
Previous studies have demonstrated high expression levels of POL III in PBMCs, whereas expression of other DNA sensors, such as cGMP-AMP synthase (cGAS), otherwise considered the dominant cytosolic DNA sensor, was relatively low in this cell population (Ogunjimi et al. 2017). Consequently, POL III may play an important role in DNA sensing in PBMCs in particular, partly explaining why POL III defects may be associated with increased susceptibility to infection with pathogens replicating in these hematopoietic cell types. In the case of VZV, both monocytes and T cells are considered important during the viremic phase of infection, and thus defects in innate VZV sensing in these cell types may predispose to high grade viremia and VZV CNS infection in POL III deficiency. In contrast, the adaptor stimulator of IFN genes (STING), acting downstream of DNA recognition through cGAS, was recently reported to participate in antiviral immunity to VZV infection in human dermal fibroblasts and keratinocytes (Kim et al. 2017). Taken together, there are now several studies suggesting that different families of DNA sensors may play individual but dominant roles in VZV infection in different cell types and tissues. Detailed immunological and virological analyses in fibroblasts, endothelial cells, and CNSresident cells will be needed in order to gain deeper insights into the immunological mechanisms controlling VZV in different anatomical compartments. This issue is particular pertinent in understanding which immune receptors and pathways are responsible for maintaining latency in sensory/ autonomic ganglia, and whether POL III plays a role in preventing VZV reactivation.

Regarding the question of specificity, the picture that emerges is that there is some degree of specificity between individual immunodeficiencies and susceptibility to different (herpes)virus infections in the CNS. For instance, it is well established that defects of the TLR3 signaling pathway increase susceptibility to HSV encephalitis (HSE) (Lim et al. 2014; Zhang et al. 2007), and remarkably, POL III mutations were not identified in whole exome sequencing of large cohorts of HSE patients (Lim et al. 2014). On the other hand, impaired POL III function is now known to predispose to VZV encephalitis in both children and adults (CarterTimofte et al. 2018b). In this setting, the specificity is hypothesized to be due to the essential role of TLR3 in intrinsic immunity to HSV1 in the CNS, whereas POL III, which mainly senses AT-rich DNA, seems to be the dominant sensor of the VZV genome (Ogunjimi et al. 2017). Indeed, it has been suggested that the particular high-AT content of the VZV genome, as opposed to the genomes of HSV and other herpesviruses, may contribute to a certain degree of specificity between POL III defects and increased susceptibility to severe VZV. Overall, the specificity and associations between individual innate sensing pathways and infection by different types of herpesviruses remain to be fully elucidated.
Based on the findings that POL III defect seems to be found in a small fraction of both children in association with primary infection/varicella and adults during reactivation, this raises the question of the role of an innate immune sensor in adaptive immunity. Whereas the available data suggest a key role in VZV DNA sensing and generation of antiviral type I IFN responses, a role for POL III in priming adaptive immune responses is certainly also a possibility. However, to date, no major adaptive immune deficiency in $\mathrm{B}$ and $\mathrm{T}$ cells has been identified in patients with VZV CNS infection during reactivation from latency (Carter-Timofte et al. 2019, 2018a). However, it is possible that POL III may act by different mechanisms in controlling VZV (viremia) during primary infection in (mainly) children as opposed to secondary infection/ reactivation in adults. Maintaining VZV latency in sensory and autonomic ganglia (Kennedy et al. 1998) may be exerted through generation of type I IFN, which has been reported to play a role in this context, or alternatively by other mechanisms in interacting with adaptive immune components, such as T cells (Gershon et al. 2015; Pourchet et al. 2017; Zerboni and Arvin 2015).

It remains an open question as to whether POL III acts exclusively through the generation of type I IFNs after innate sensing of foreign DNA in the cytosol, or whether POL III may also exert antiviral functions through other mechanisms, possibly in the nucleus. The basis for such speculations comes from a recent study demonstrating an antiviral role of a POL III-generated 5S ribosomal RNA pseudogene transcript RNA5SP14 during HSV infection (Chiang et al. 2018). The mechanism was demonstrated to involve release of the otherwise protein bound RNA5SP14 transcript secondary to virusinduced shutdown of cellular protein synthesis, thereby allowing the transcript to relocalise from the nucleus to the cytosol and to stimulate RIG-I-dependent IFN $\alpha / \beta$ production (Chiang et al. 2018).

Further investigations of the molecular and cellular mechanisms are required to confirm or clarify the role of IFNmediated immunity in VZV infection. More specifically, it remains to be determined whether POL III is a VZV-specific antiviral immune sensor, possibly related to the particularly AT richness of the VZV genome, and whether it exerts its role in the nucleus or exclusively in the cytoplasm (Carter-Timofte et al. 2018b). In this context, it is also important to clarify the expression of different VZV pattern recognition receptors (PRRs) in different cell types, and the level of redundancy. These factors may provide insights into protective immunity to VZV and whether failing immune mechanisms predisposing to $\mathrm{VZV}$ infection in the CNS are failing mainly in the periphery, e.g., during the viremic phases of infection or the latency mechanisms in the sensory ganglia, or, in the brain parenchyma after VZV has gained access into the CNS. A major portion of the defect may well be in clearing tissue infection, since progressive tissue infection is the deleterious 
outcome. Importantly, it remains unknown how prevalent the POL III defect is in the population. Of clinical importance, answering some of these questions should be relevant to decisions regarding prophylaxis and treatment of VZV CNS infections.

Overall, T cell and NK cell defects tend to cause mainly severe skin and mucous manifestations, whereas defects involving innate IFN signaling are more fulminating and prone to involve CNS complications. Therefore, further cellular and molecular characterization of these PIDs are warranted to clarify the contributions from T, NK, and tissue-resident cells as well as type I and II IFN in the context of VZV infection.

\section{Secondary immunodeficiencies/immunosuppression in VZV CNS infection}

In addition to genetically determined primary immunodeficiencies, a number of other conditions, i.e., secondary immunodeficiencies, encompassing malignancy, transplantation, HIV infection/AIDS, immunosuppressive medication, and age-related immune decline, may also predispose to severe VZV infection, including CNS infection.

\section{Cancer and transplantation}

Among the first conditions recognized to increase significantly the risk of severe disseminated VZV reactivation were cancer (Schimpff et al. 1972; Sokal and Firat 1965; Wong and Hirsch 1984) and hematopoietic or solid organ transplantation (Champlin and Gale 1984; Luby et al. 1977), mostly ascribed to the significant decline in cellular immunity in these conditions. Moreover, various classes of chemotherapy will invariably increase the risk of VZV complications. For example, treatment of multiple myeloma patients with the proteasome inhibitor bortezomib was associated with a $13 \%$ risk of VZV reactivation (Chanan-Khan et al. 2008). Another study specifically addressed the prevalence of severe VZV manifestations, including VZV encephalitis and disseminated VZV, in multiple myeloma patients treated with the thalidomide-derivative lenalidomide and reported such complications in 10 of 93 patients (Konig et al. 2014). Likewise, a substantial number (10 out of 132) patients experienced VZV reactivation within 2 years of stem cell transplantation (Konig et al. 2014). Neurological manifestations of VZV reactivation during treatment of non-solid malignancies have also been described (De Broucker et al. 2012; Rodenburg et al. 2017; Tattevin et al. 2001). This was confirmed by results from the Swiss transplantation cohort recently reporting on severe VZV reactivation in patients following solid organ transplantation (van Delden et al. 2020). Presentation with HLH was described in two adolescents on immunosuppressive therapy for graftversus-host disease after atypical and severe VZV reactivation (van der Werff ten Bosch et al. 2009). On the other hand, it is important to note that VZV neurological complications have also been documented in a case series in which only half of patients suffered from a known immunodeficiency (Becerra et al. 2013; De Broucker et al. 2012).

\section{HIV/AIDS}

During the emergence of HIV and AIDS, it became clear that VZV is a cause of CNS infection in HIV-infected individuals with severely impaired CD4 T cell immunity (Burke et al. 1997; Gray et al. 1994; Kennedy 1988; Whitley and Gnann Jr. 1995). In a large study of more than 500 HIV patients with neurological disorders, VZV was diagnosed in the CNS in $2.5 \%$, underscoring that VZV is only one among several other infectious complications in this patient group (Cinque et al. 1996). Based on other studies, VZV reactivation with CNS and ocular manifestations was estimated to occur in up to $11 \%$ of HIV positive individuals before the introduction of highly active antiviral therapy (HAART) (Burke et al. 1997). Investigation of CSF samples from HIV positive individuals revealed anti-VZV intrathecal antibody synthesis in $16 \%$, suggesting a significant disease burden of subclinical VZV CNS infection in this patient population (Birlea et al. 2011). Reactivation of VZV in the CNS in AIDS patients is generally associated with a severe diffuse meningoencephalitis, and in some cases, vasculitis, granulomatous angiitis or myelitis (Gilden et al. 2009; Corti et al. 2015; Kennedy 1988). Although myelitis is an extremely rare complication of VZV infection, it is relatively more prevalent in immunocompromised individuals, including AIDS patients, who are prone to atypical presentations and poorer outcomes (Manian et al. 1995). Chronic VZV encephalitis is seen almost exclusively in AIDS patients and manifests with multifocal lesions in the white matter with small vessel vasculitis and demyelinization as well as ischemic and hemorrhagic infarcts (Gnann Jr. 2002; Kleinschmidt-DeMasters et al. 1996). Moreover, several cases of VZV aneurysmal vasculopathy have been reported, and indeed it is possible that many cases of HIV-associated vasculopathy are in reality cases of VZV vasculopathy (Gilden et al. 2009; Tomkins et al. 2018). As an additional complicating factor, VZV-mediated vasculitis presenting as stroke may be caused by underlying CNS immune reconstitution inflammatory syndrome (IRIS) during introduction of antiviral treatment in severely immunocompromised patients (Newsome and Nath 2009; Teo et al. 2014), largely mediated by CD8+ $\mathrm{T}$ cells (Venkataramana et al. 2006) and requiring corticosteroids for dampening immune responses and for clinical stabilization. A very rare manifestation of VZV meningitis with CSF cytological changes suggestive of primary CNS lymphoma due to large lymphoid cells has also been described, suggesting caution in the differential diagnosis between viral meningitis and lymphoma, particularly in HIV-infected patients (Park et al. 2003). Although less frequently encountered 
since the introduction of HAART, ocular manifestation associated with VZV reactivation represents a well-established clinical spectrum occurring more frequently in AIDS patients than in immunocompetent individuals (Batisse et al. 1996; Franco-Paredes et al. 2002; Galindez et al. 1996; Liu et al. 2005). Finally, zoster, particularly when occurring in younger individuals, may be an indicator disease of underlying HIV infection, although it is entirely possible to experience zoster without any obvious immunodeficiency (Melbye et al. 1987; Sogaard et al. 2012).

\section{VZV reactivation during treatment with immunomodulatory medications}

Secondary immunosuppression through various immunomodulating therapies is a well-established and increasing problem, particularly given that indications for the use of such therapies in rheumatology, gastroenterology, dermatology, neurology, etc. are steadily increasing as are both the spectrum and the availability of such medications. Drugs that interfere with $\mathrm{T}$ cell and NK cell immunity or with innate type I IFN responses might be expected to increase the risk of severe VZV, including VZV CNS complications, whereas drugs interfering with humoral immunity are more likely to cause a less severe risk of viral infection.

Natalizumab, an anti- $\alpha 4 \beta 1$-integrin antibody inhibiting leukocyte migration across the blood brain barrier into the CNS utilized in the treatment of multiple sclerosis (MS), has been reported to be associated with progressive multifocal leukoencephalopathy (PML) caused by JC virus, and also increases the risk of VZV encephalitis and myelitis (Bourre et al. 2013; Fine et al. 2013; Yeung et al. 2013). The antiCD52 antibody alemtuzumab approved for the treatment of MS and leukemia, which depletes circulating $\mathrm{T}$ and $\mathrm{B}$ cells, was also reported to cause severe VZV infection, although not involving the CNS (Williamson and Berger 2015). This drug would be a mild mimic of SCID with the absence of B, T, and NK cells. Another drug used for the treatment of MS is the sphingosine-1-phosphate-receptor-modulator fingolimod, which has also been related to several examples of fulminating cases of disseminated VZV infection, encephalitis, and vasculitis, alone or in combination with other immunomodulating agents (Bourdette and Gilden 2012; Cohen et al. 2010; Issa and Hentati 2015; Ratchford et al. 2012). The mechanism whereby fingolimod predisposes to VZV reactivation is not well understood but has been suggested to stem from the trapping of naïve and memory $\mathrm{T}$ cells in lymph nodes causing insufficient $\mathrm{T}$ effector cell function to maintain VZV latency (Williamson and Berger 2015).

In addition to the specific examples mentioned above, several studies have reported an increased risk of VZV reactivation in patients with autoimmune conditions receiving various different immunosuppressive medications, including anti-
TNF $\alpha$ treatment (Burmester et al. 2014; Strangfeld et al. 2009), including cases of zoster ophthalmicus and meningitis (Serac et al. 2012), glucocorticoids, cyclophosphamide, azathioprine, leflunomide, anti-IL-1, anti-IL-6, and methotrexate (Antonelli et al. 1991; Cacciapaglia et al. 2015; Wolfe et al. 2006), although conflicting results have been obtained for the latter (Zhang et al. 2012). It is, however, clear that the combination of Methotrexate with glucocorticoid is a risk factor for VZV reactivation (McLean-Tooke et al. 2009). While some of these cases were severe, they were characterized by severe cutaneous or disseminated VZV infection rather than infection in the CNS (Cacciapaglia et al. 2015). Among the immune checkpoint inhibitors, severe disseminated VZV was also reported, particular for anti-CTLA4 inhibitors interfering with T cell activation (Del Castillo et al. 2016).

Within the group of more recently introduced immunosuppressive medications, the JAK inhibitors are relevant. These selective inhibitors of Janus kinases act to block JAK-STAT signaling downstream of the type I, II, and III IFN receptors. All JAKs play an important role in immune response and development, with JAK1 and JAK2 also involved in hematopoiesis. JAK1 is required for both type I and type II IFN signaling pathways, whereas JAK3 is essential for lymphocyte development and function (Mogensen 2018). JAK inhibitors are utilized and approved for treating autoinflammatory conditions, in which type I IFN and IFN-stimulated gene (ISG) signatures in blood are prominent, the so-called interferonopathies, such as Aicardi-Goutieres syndrome, STING-associated vasculopathy with onset in infancy (SAVI), STAT1 gain of function, and chronic atypical neutrophilic dermatosis with lipodystrophy and elevated temperature (CANDLE) (Crow 2011; Sanchez et al. 2018). Additionally, JAK inhibitors have been approved for the treatment of rheumatoid arthritis, psoriasis, and inflammatory bowel disease when other treatments fail (Colombel 2018). Interestingly, the major infection risk noticed so far has been VZV reactivation, and this effect appears to be relatively specific for VZV, since no other viral infections were noted (Colombel 2018; Harigai 2019; Marra et al. 2016; Sandborn et al. 2017; Winthrop et al. 2016). Specifically, VZV meningoencephalitis was described in a patient receiving the JAK inhibitor ruxolitinib for myelofibrosis (Eyal et al. 2017). In line with these findings, VZV reactivation/zoster was also reported in studies using anti-IFN $\alpha$ antibodies to treat systemic lupus erythematosus (Furie et al. 2017). These secondary immunodeficiencies thus represent the correlate of the findings in PIDs either interfering with induction of type I IFN responses as seen in POL III and TLR3 deficiencies, or interfering with responses to type I and type II IFN as documented in STAT1 LOF and TYK2 deficiencies and thus underscore the fundamental importance of IFNs in protective immunity against VZV. 
Overall, VZV reactivation is more common in patients with rheumatoid arthritis and systemic lupus erythematosus, because of their inherently disturbed immune system (Forbes et al. 2014). Indeed, it should always be remembered that the emergence of opportunistic infection, including VZV reactivation, in individuals with autoimmune and autoinflammatory diseases and treatment with immunomodulatory medications, represents the combined effect of the immunedysregulation imparted by the diseases per se together with the immunosuppression exerted by the drug.

\section{Other factors predisposing to VZV reactivation}

Waning immunity occurring with increasing age is associated with a significantly increased risk of VZV reactivation, usually causing herpes zoster which may be accompanied by CSF pleocytosis and a degree of meningitis or, more rarely, encephalitis (Gilden et al. 2009; Thomas and Hall 2004). This increased susceptibility to VZV reactivation is attributed mainly to a general decrease in cellular immunity, and, possibly more specifically, to reduced levels of protective immunity after primary varicella or VZV vaccination in childhood. Other epidemiological factors influencing the risk of VZV reactivation are recent varicella exposure (protective), time of primary infection/varicella, sex, ethnicity, and possibly psychological and social stress-related factors (Thomas and Hall 2004). For example, a large community-based study reported a strong protective effect associated with recent contacts with varicella patients (Garnett and Grenfell 1992; Thomas et al. 2002), and another study found a trend towards reduced risk of zoster in people born in subtropical/tropical countries with evidence of late-onset varicella (Longfield et al. 1990). Moreover, women appear to be at increased risk, whereas some studies have suggested a lower risk in non-whites, although the specific immunological or genetic correlates of these findings are not entirely clear (Nagasako et al. 2003). However, none of the epidemiological studies cited above specifically addressed the risk of VZV CNS disease in the setting of VZV reactivation in these different populations.

\section{Conclusion}

VZV infection can be largely prevented in the general population, since VZV vaccines that provide effective protection have been developed, including a live attenuated vaccine against varicella and a subunit vaccine for adults and the elderly against herpes zoster. However, a particular problem remains in individuals with severe PID, particularly in cases of profound cellular PID, in whom the live vaccine may pose a threat for serious disseminated VZV infection. More research is required to define more precisely the role of VZV immunization in immunosuppressed individuals. With increased clinical use of a wide variety of immunosuppressive drugs for an increasing number of clinical conditions, it seems very likely that the frequency and range of VZV infections, including those specifically affecting the central and peripheral nervous systems, will be reported. Host immune factors seem to be more important than intrinsic virological factors in predisposing susceptible individuals to VZV infections, but the specific molecular pathways involved in these remain to be elucidated in greater detail.

\section{Compliance with ethical standards}

Conflict of interest The authors declare that they have no conflict of interest.

Open Access This article is licensed under a Creative Commons Attribution 4.0 International License, which permits use, sharing, adaptation, distribution and reproduction in any medium or format, as long as you give appropriate credit to the original author(s) and the source, provide a link to the Creative Commons licence, and indicate if changes were made. The images or other third party material in this article are included in the article's Creative Commons licence, unless indicated otherwise in a credit line to the material. If material is not included in the article's Creative Commons licence and your intended use is not permitted by statutory regulation or exceeds the permitted use, you will need to obtain permission directly from the copyright holder. To view a copy of this licence, visit http://creativecommons.org/licenses/by/4.0/.

\section{References}

Abdollahpour H, Appaswamy G, Kotlarz D, Diestelhorst J, Beier R, Schaffer AA, Gertz EM, Schambach A, Kreipe HH, Pfeifer D et al (2012) The phenotype of human STK4 deficiency. Blood 119: 3450-3457

Ablasser A, Bauernfeind F, Hartmann G, Latz E, Fitzgerald KA, Hornung V (2009) RIG-I-dependent sensing of poly(dA:dT) through the induction of an RNA polymerase III-transcribed RNA intermediate. Nat Immunol 10:1065-1072

Abolhassani H, Edwards ES, Ikinciogullari A, Jing H, Borte S, Buggert M, Du L, Matsuda-Lennikov M, Romano R, Caridha R et al (2017) Combined immunodeficiency and Epstein-Barr virus-induced B cell malignancy in humans with inherited CD70 deficiency. J Exp Med 214:91-106

Al-Herz W, Essa S (2019) Spectrum of viral infections among primary immunodeficient children: report from a national registry. Front Immunol 10:1231

Albert MH, Notarangelo LD, Ochs HD (2011) Clinical spectrum, pathophysiology and treatment of the Wiskott-Aldrich syndrome. Curr Opin Hematol 18:42-48

Alkhairy OK, Perez-Becker R, Driessen GJ, Abolhassani H, van Montfrans J, Borte S, Choo S, Wang N, Tesselaar K, Fang M et al (2015) Novel mutations in TNFRSF7/CD27: clinical, immunologic, and genetic characterization of human CD27 deficiency. J Allergy Clin Immunol 136(703-712):e710

Antonelli MA, Moreland LW, Brick JE (1991) Herpes zoster in patients with rheumatoid arthritis treated with weekly, low-dose methotrexate. Am J Med 90:295-298

Armangue T, Moris G, Cantarin-Extremera V, Conde CE, Rostasy K, Erro ME, Portilla-Cuenca JC, Turon-Vinas E, Malaga I, Munoz- 
Cabello B et al (2015) Autoimmune post-herpes simplex encephalitis of adults and teenagers. Neurology 85:1736-1743

Arvin AM, Moffat JF, Sommer M, Oliver S, Che X, Vleck S, Zerboni L, $\mathrm{Ku}$ CC (2010) Varicella-zoster virus T cell tropism and the pathogenesis of skin infection. Curr Top Microbiol Immunol 342:189209

Batisse D, Eliaszewicz M, Zazoun L, Baudrimont M, Pialoux G, Dupont B (1996) Acute retinal necrosis in the course of AIDS: study of 26 cases. AIDS 10:55-60

Becerra JC, Sieber R, Martinetti G, Costa ST, Meylan P, Bernasconi E (2013) Infection of the central nervous system caused by varicella zoster virus reactivation: a retrospective case series study. Int J Infect Dis 17:e529-e534

Bernard G, Chouery E, Putorti ML, Tetreault M, Takanohashi A, Carosso G, Clement I, Boespflug-Tanguy O, Rodriguez D, Delague V et al (2011) Mutations of POLR3A encoding a catalytic subunit of RNA polymerase Pol III cause a recessive hypomyelinating leukodystrophy. Am J Hum Genet 89:415-423

Bezrodnik L, Di Giovanni D, Caldirola MS, Azcoiti ME, Torgerson T, Gaillard MI (2015) Long-term follow-up of STAT5B deficiency in three argentinian patients: clinical and immunological features. J Clin Immunol 35:264-272

Birlea M, Arendt G, Orhan E, Schmid DS, Bellini WJ, Schmidt C, Gilden D, Cohrs RJ (2011) Subclinical reactivation of varicella zoster virus in all stages of HIV infection. J Neurol Sci 304:22-24

Biron CA, Byron KS, Sullivan JL (1989) Severe herpesvirus infections in an adolescent without natural killer cells. N Engl J Med 320:17311735

Bode SF, Lehmberg K, Maul-Pavicic A, Vraetz T, Janka G, Stadt UZ, Ehl $S$ (2012) Recent advances in the diagnosis and treatment of hemophagocytic lymphohistiocytosis. Arthritis Res Ther 14:213

Bourdette D, Gilden D (2012) Fingolimod and multiple sclerosis: four cautionary tales. Neurology 79:1942-1943

Bourre B, Lefaucheur R, Ahtoy P, Travers F, Fetter D (2013) Varicellazoster virus acute myelitis in a patient with MS treated with natalizumab. Neurology 81:1966-1967

Burke DG, Kalayjian RC, Vann VR, Madreperla SA, Shick HE, Leonard DG (1997) Polymerase chain reaction detection and clinical significance of varicella-zoster virus in cerebrospinal fluid from human immunodeficiency virus-infected patients. J Infect Dis 176:1080 1084

Buckingham EM, Foley MA, Grose C, Syed NA, Smith ME, Margolis TP, Thurtell MJ, Kardon R (2018) Identification of herpes zosterassociated temporal arteritis among cases of giant cell arteritis. Am J Ophthalmol 187:51-60.

Burmester GR, Rubbert-Roth A, Cantagrel A, Hall S, Leszczynski P, Feldman D, Rangaraj MJ, Roane G, Ludivico C, Lu P et al (2014) A randomised, double-blind, parallel-group study of the safety and efficacy of subcutaneous tocilizumab versus intravenous tocilizumab in combination with traditional disease-modifying antirheumatic drugs in patients with moderate to severe rheumatoid arthritis (SUMMACTA study). Ann Rheum Dis 73:69-74

Cacciapaglia F, Zuccaro C, Iannone F (2015) Varicella-zoster virus infection in rheumatoid arthritis patients in the anti-tumour necrosis factor era. Clin Exp Rheumatol 33:917-923

Carter-Timofte ME, Hansen AF, Christiansen M, Paludan SR, Mogensen TH (2019) Mutations in RNA polymerase III genes and defective DNA sensing in adults with varicella-zoster virus CNS infection. Genes Immun 20:214-223

Carter-Timofte ME, Hansen AF, Mardahl M, Fribourg S, Rapaport F, Zhang SY, Casanova JL, Paludan SR, Christiansen M, Larsen CS, Mogensen TH (2018a) Varicella-zoster virus CNS vasculitis and RNA polymerase III gene mutation in identical twins. Neurol Neuroimmunol Neuroinflamm 7;5(6):e500. https://doi.org/10. 1212/NXI.0000000000000500
Carter-Timofte ME, Paludan SR, Mogensen TH (2018b) RNA polymerase III as a gatekeeper to prevent severe VZV infections. Trends Mol Med 24:904-915

Champlin RE, Gale RP (1984) The early complications of bone marrow transplantation. Semin Hematol 21:101-108

Chanan-Khan A, Sonneveld P, Schuster MW, Stadtmauer EA, Facon T, Harousseau JL, Ben-Yehuda D, Lonial S, Goldschmidt H, Reece D, Neuwirth R, Anderson KC, Richardson PG (2008) Analysis of herpes zoster events among bortezomib-treated patients in the phase III APEX study. J Clin Oncol 26:4784-4790

Chaudhuri A, Kennedy PGE (2002) Diagnosis and treatment of viral encephalitis. Postgrad Med J 78(924):575-583

Chiang JJ, Sparrer KMJ, van Gent M, Lassig C, Huang T, Osterrieder N, Hopfner KP, Gack MU (2018) Viral unmasking of cellular 5S rRNA pseudogene transcripts induces RIG-I-mediated immunity. Nat Immunol 19:53-62

Chiu YH, Macmillan JB, Chen ZJ (2009) RNA polymerase III detects cytosolic DNA and induces type I interferons through the RIG-I pathway. Cell 138:576-591

Cinque P, Vago L, Dahl H, Brytting M, Terreni MR, Fornara C, Racca S, Castagna A, Monforte AD, Wahren B, Lazzarin A, Linde A (1996) Polymerase chain reaction on cerebrospinal fluid for diagnosis of virus-associated opportunistic diseases of the central nervous system in HIV-infected patients. AIDS 10:951-958

Cohen JA, Barkhof F, Comi G, Hartung HP, Khatri BO, Montalban X, Pelletier J, Capra R, Gallo P, Izquierdo G, Tiel-Wilck K, de Vera A, Jin J, Stites T, Wu S, Aradhye S, Kappos L, TRANSFORMS Study Group (2010) Oral fingolimod or intramuscular interferon for relapsing multiple sclerosis. N Engl J Med 362:402-415

Colombel JF (2018) Herpes zoster in patients receiving JAK inhibitors for ulcerative colitis: mechanism, epidemiology, management, and prevention. Inflamm Bowel Dis 24:2173-2182

Corti M, Villafane MF, Vittar N, Banco MC, Priarone M, Mammana L, Gilardi L (2015) Meningoencephalitis due to varicella zoster virus in aids patients. Report of eleven cases and review of the literature. Rev Inst Med Trop Sao Paulo 57:505-508

Cottineau J, Kottemann MC, Lach FP, Kang YH, Vely F, Deenick EK, Lazarov T, Gineau L, Wang Y, Farina A et al (2017) Inherited GINS1 deficiency underlies growth retardation along with neutropenia and NK cell deficiency. J Clin Invest 127:1991-2006

Crow YJ (2011) Type I interferonopathies: a novel set of inborn errors of immunity. Ann N Y Acad Sci 1238:91-98

Cui Y, Keles S, Charbonnier LM, Jule AM, Henderson L, Celik SC, Reisli I, Shen C, Xie WJ, Schmitz-Abe K et al (2020) Combined immunodeficiency caused by a loss-of-function mutation in DNA polymerase delta 1. J Allergy Clin Immunol 145(391-401):e398

De Broucker T, Mailles A, Chabrier S, Morand P, Stahl JP, Steering C, investigators, $g$ (2012) Acute varicella zoster encephalitis without evidence of primary vasculopathy in a case-series of 20 patients. Clin Microbiol Infect 18:808-819

Del Castillo M, Romero FA, Arguello E, Kyi C, Postow MA, RedelmanSidi G (2016) The spectrum of serious infections among patients receiving immune checkpoint blockade for the treatment of melanoma. Clin Infect Dis 63:1490-1493

Dobbs K, Dominguez Conde C, Zhang SY, Parolini S, Audry M, Chou J, Haapaniemi E, Keles S, Bilic I, Okada S et al (2015) Inherited DOCK2 deficiency in patients with early-onset invasive infections. N Engl J Med 372:2409-2422

Duncan CJ, Hambleton S (2015) Varicella zoster virus immunity: a primer. J Inf Secur 71(Suppl 1):S47-S53

Dupuis S, Jouanguy E, Al-Hajjar S, Fieschi C, Al-Mohsen IZ, Al-Jumaah S, Yang K, Chapgier A, Eidenschenk C, Eid P et al (2003) Impaired response to interferon-alpha/beta and lethal viral disease in human STAT1 deficiency. Nat Genet 33:388-391 
Eyal O, Flaschner M, Ben Yehuda A, Rund D (2017) Varicella-zoster virus meningoencephalitis in a patient treated with ruxolitinib. Am J Hematol 92:E74-E75

Fine AJ, Sorbello A, Kortepeter C, Scarazzini L (2013) Central nervous system herpes simplex and varicella zoster virus infections in natalizumab-treated patients. Clin Infect Dis 57:849-852

Fischer A, Notarangelo LD, Neven B, Cavazzana M, Puck JM (2015) Severe combined immunodeficiencies and related disorders. Nat Rev Dis Primers 1:15061

Forbes HJ, Bhaskaran K, Thomas SL, Smeeth L, Clayton T, Langan SM (2014) Quantification of risk factors for herpes zoster: population based case-control study. BMJ 348:g2911

Franco-Paredes C, Bellehemeur T, Merchant A, Sanghi P, DiazGranados C, Rimland D (2002) Aseptic meningitis and optic neuritis preceding varicella-zoster progressive outer retinal necrosis in a patient with AIDS. AIDS 16:1045-1049

Furie R, Khamashta M, Merrill JT, Werth VP, Kalunian K, Brohawn P, Illei GG, Drappa J, Wang L, Yoo S, for the CD1013 Study Investigators (2017) Anifrolumab, an anti-interferon-alpha receptor monoclonal antibody, in moderate-to-severe systemic lupus erythematosus. Arthritis Rheum 69:376-386

Galindez OA, Sabates NR, Whitacre MM, Sabates FN (1996) Rapidly progressive outer retinal necrosis caused by varicella zoster virus in a patient infected with human immunodeficiency virus. Clin Infect Dis 22:149-151

Garnett GP, Grenfell BT (1992) The epidemiology of varicella-zoster virus infections: the influence of varicella on the prevalence of herpes zoster. Epidemiol Infect 108:513-528

Garry EM, Delaney A, Anderson HA, Sirinathsinghji EC, Clapp RH, Martin WJ, Kinchington PR, Krah DL, Abbadie C, FleetwoodWalker SM (2005) Varicella zoster virus induces neuropathic changes in rat dorsal root ganglia and behavioural reflex sensitisation that is blocked by gabapentin orsodium channel blocking drugs. Pain 118:97-111

Gershon AA, Breuer J, Cohen JI, Cohrs RJ, Gershon MD, Gilden D, Grose C, Hambleton S, Kennedy PG, Oxman MN et al (2015) Varicella zoster virus infection. Nat Rev Dis Primers 1:15016

Gilden D, Cohrs RJ, Mahalingam R, Nagel MA (2009) Varicella zoster virus vasculopathies: diverse clinical manifestations, laboratory features, pathogenesis, and treatment. Lancet Neurol 8:731-740

Gilden DH, Kleinschmidt-DeMasters BK, LaGuardia JJ, Mahalingam R, Cohrs RJ (2000) Neurologic complications of the reactivation of varicella-zoster virus. N Engl J Med 342:635-645

Gilden D, White T, Khmeleva N, Heintzman A, Choe A, Boyer PJ, Grose C, Carpenter JE, Rempel A, Bos N, Kandasamy B, Lear-Kaul K, Holmes DB, Bennett JL, Cohrs RJ, Mahalingam R, Mandava N, Eberhart CG, Bockelman B, Poppiti RJ, Tamhankar MA, Fogt F, Amato M, Wood E, Durairaj V, Rasmussen S, Petursdottir V, Pollak L, Mendlovic S, Chatelain D, Keyvani K, Brueck W, Nagel MA (2015) Prevalence and distribution of VZV in temporal arteries of patients with giant cell arteritis. Neurology 84:1948-1955

Gilden DH, Wright RR, Schneck SA, Gwaltney JM Jr, Mahalingam R (1994) Zoster sine herpete, a clinical variant. Ann Neurol 35:530 533

Gineau L, Cognet C, Kara N, Lach FP, Dunne J, Veturi U, Picard C, Trouillet C, Eidenschenk C, Aoufouchi S, Alcaïs A, Smith O, Geissmann F, Feighery C, Abel L, Smogorzewska A, Stillman B, Vivier E, Casanova JL, Jouanguy E (2012) Partial MCM4 deficiency in patients with growth retardation, adrenal insufficiency, and natural killer cell deficiency. J Clin Invest 122:821-832

Gnann JW Jr (2002) Varicella-zoster virus: atypical presentations and unusual complications. J Infect Dis 186(Suppl 1):S91-S98

Gray F, Belec L, Lescs MC, Chretien F, Ciardi A, Hassine D, FlamentSaillour M, de Truchis P, Clair B, Scaravilli F (1994) Varicellazoster virus infection of the central nervous system in the acquired immune deficiency syndrome. Brain 117(Pt 5):987-999
Harigai M (2019) Growing evidence of the safety of JAK inhibitors in patients with rheumatoid arthritis. Rheumatology (Oxford) 58:i34 i42

Heusinkveld LE, Yim E, Yang A, Azani AB, Liu Q, Gao JL, McDermott DH, Murphy PM (2017) Pathogenesis, diagnosis and therapeutic strategies in WHIM syndrome immunodeficiency. Expert Opin Orphan Drugs 5:813-825

Hope-Simpson RE (1965) The nature of herpes zoster: a long-term study and a new hypothesis. Proc R Soc Med 58:9-20

Hsu AP, Sampaio EP, Khan J, Calvo KR, Lemieux JE, Patel SY, Frucht DM, Vinh DC, Auth RD, Freeman AF, Olivier KN, Uzel G, Zerbe CS, Spalding C, Pittaluga S, Raffeld M, Kuhns DB, Ding L, Paulson ML, Marciano BE, Gea-Banacloche JC, Orange JS, CuellarRodriguez J, Hickstein DD, Holland SM (2011) Mutations in GATA2 are associated with the autosomal dominant and sporadic monocytopenia and mycobacterial infection (MonoMAC) syndrome. Blood 118:2653-2655

Issa NP, Hentati A (2015) VZV encephalitis that developed in an immunized patient during fingolimod therapy. Neurology 84:99-100

Jemsek J, Greenberg SB, Taber L, Harvey D, Gershon A, Couch RB (1983) Herpes zoster-associated encephalitis: clinicopathologic report of 12 cases and review of the literature. Medicine (Baltimore) 162(2):81-97

Johnson R, Milbourn PE (1970) Central nervous system manifestations of chickenpox. Can Med Assoc J 102(8):831-834

Kennedy PGE (1987) Neurological complications of varicella-zoster virus infections. In: Kennedy PGE, Johnson RT (eds) Infections of the Nervous System. Butterworths, pp 177-208

Kennedy PGE (1988) Neurological complications of human immunodeficiency virus infection. Postgrad Med J 64:180-187

Kennedy PGE (2011) Zoster sine herpete: it would be rash to ignore it. Neurology 76:416-7

Kennedy PGE (2016) Issues in the treatment of neurological conditions caused by reactivation of varicella zoster virus (VZV). Neurotherapeutics. 13(3):509-513. https://doi.org/10.1007/s13311016-0430-x

Kennedy PGE, Gershon AA (2018) Clinical features of varicella-zoster virus infection. Viruses. 10(11). E609. https://doi.org/10.3390/ v10110609

Kennedy PGE, Grinfeld E, Esiri M (2003) Absence of detection of varicella-zoster virus infection in temporal artery biopsies from patients with giant cell arteritis. J Neurol Sci 215:27-29

Kennedy PGE, Grinfeld E, Gow JW (1998) Latent varicella-zoster virus is located predominantly in neurons in human trigeminal ganglia. Proc Natl Acad Sci U S A 95:4658-4662

Kennedy PGE, Montague P, Scott F, Grinfeld E, Ashrafi GH, Breuer J, Rowan EG (2013) Varicella-zoster viruses associated with postherpetic neuralgia induce sodium current density increases in the ND7-23 Nav-1.8 neuroblastoma cell line. PLoS One. 8(1):e51570. https://doi.org/10.1371/journal.pone.0051570

Kim JA, Park SK, Seo SW, Lee CH, Shin OS (2017) STING is involved in antiviral immune response against VZV infection via the induction of type I and III IFN pathways. J Invest Dermatol 137:21012109

Kleinschmidt-DeMasters BK, Amlie-Lefond C, Gilden DH (1996) The patterns of varicella zoster virus encephalitis. Hum Pathol 27:927938

Konig C, Kleber M, Reinhardt H, Knop S, Wasch R, Engelhardt M (2014) Incidence, risk factors, and implemented prophylaxis of varicella zoster virus infection, including complicated varicella zoster virus and herpes simplex virus infections, in lenalidomide-treated multiple myeloma patients. Ann Hematol 93:479-484

Kreins AY, Ciancanelli MJ, Okada S, Kong XF, Ramirez-Alejo N, Kilic SS, El Baghdadi J, Nonoyama S, Mahdaviani SA, Ailal F et al (2015) Human TYK2 deficiency: mycobacterial and viral infections without hyper-IgE syndrome. J Exp Med 212:1641-1662 
Lim HK, Seppanen M, Hautala T, Ciancanelli MJ, Itan Y, Lafaille FG, Dell W, Lorenzo L, Byun M, Pauwels E, Ronnelid Y, Cai X, Boucherit S, Jouanguy E, Paetau A, Lebon P, Rozenberg F, Tardieu M, Abel L, Yildiran A, Vergison A, Roivainen R, Etzioni A, Tienari PJ, Casanova JL, Zhang SY (2014) TLR3 deficiency in herpes simplex encephalitis: high allelic heterogeneity and recurrence risk. Neurology 83:1888-1897

Liu JZ, Brown P, Tselis A (2005) Unilateral retrobulbar optic neuritis due to varicella zoster virus in a patient with AIDS: a case report and review of the literature. J Neurol Sci 237:97-101

Longfield JN, Winn RE, Gibson RL, Juchau SV, Hoffman PV (1990) Varicella outbreaks in Army recruits from Puerto Rico. Varicella susceptibility in a population from the tropics. Arch Intern Med 150:970-973

Luby JP, Ramirez-Ronda C, Rinner S, Hull A, Vergne-Marini P (1977) A longitudinal study of varicella-zoster virus infections in renal transplant recipients. J Infect Dis 135:659-663

Manian FA, Kindred M, Fulling KH (1995) Chronic varicella-zoster virus myelitis without cutaneous eruption in a patient with AIDS: report of a fatal case. Clin Infect Dis 21:986-988

Marra F, Lo E, Kalashnikov V, Richardson K (2016) Risk of herpes zoster in individuals on biologics, disease-modifying antirheumatic drugs, and/or corticosteroids for autoimmune diseases: a systematic review and meta-analysis. Open Forum Infect Dis 3:ofw205. https:// doi.org/10.1093/ofid/ofw205

McLean-Tooke A, Aldridge C, Waugh S, Spickett GP, Kay L (2009) Methotrexate, rheumatoid arthritis and infection risk: what is the evidence? Rheumatology (Oxford) 48:867-871

Melbye M, Grossman RJ, Goedert JJ, Eyster ME, Biggar RJ (1987) Risk of AIDS after herpes zoster. Lancet 1:728-731

Mogensen TH (2018) IRF and STAT transcription factors - from basic biology to roles in infection, protective immunity, and primary immunodeficiencies. Front Immunol 9:3047

Nagel MA, Forghani B, Mahalingam R, Wellish MC, Cohrs RJ, Russman AN, Katzan I, Lin R, Gardner CJ, Gilden DH (2007) The value of detecting anti-VZV IgG antibody in CSF to diagnose VZV vasculopathy. Neurology 68:1069-1073

Nagel MA, Gilden DH (2007) The protean neurologic manifestations of varicella-zoster virus. Cleve Clin J Med 74:489-504

Nagel MA, Gilden D (2014) Update on varicella zoster virus vasculopathy. Curr Infect Dis Rep 16:407

Nagel MA, White T, Khmeleva N, Rempel A, Boyer PJ, Bennett JL, Haller A, Lear-Kaul K, Kandasmy B, Amato M, Wood E, Durairaj V, Fogt F, Tamhankar MA, Grossniklaus HE, Poppiti RJ, Bockelman B, Keyvani K, Pollak L, Mendlovic S, Fowkes M, Eberhart CG, Buttmann M, Toyka KV, Meyer-ter-Vehn T, Petursdottir V, Gilden D (2015) Analysis of varicella-zoster virus in temporal arteries biopsy positive and negative for giant cell arteritis. JAMA Neurol 72:1281-1287

Nagasako EM, Johnson RW, Griffin DR, Elpern DJ, Dworkin RH (2003) Geographic and racial aspects of herpes zoster. J Med Virol 70(Suppl 1):S20-S23

Newsome SD, Nath A (2009) Varicella-zoster virus vasculopathy and central nervous system immune reconstitution inflammatory syndrome with human immunodeficiency virus infection treated with steroids. J Neuro-Oncol 15:288-291

Ogunjimi B, Zhang SY, Sorensen KB, Skipper KA, Carter-Timofte M, Kerner G, Luecke S, Prabakaran T, Cai Y, Meester J et al (2017) Inborn errors in RNA polymerase III underlie severe varicella zoster virus infections. J Clin Invest 127:3543-3556

Ostrowski RA, Metgud S, Tehrani R, Walter M, Jay WM (2019) Varicella zoster virus in giant cell arteritis: a review of current medical literature. Neuro-Ophthalmology 43(3):159-170

Park S, Leymarie V, Agbalika F, Galicier L, Oksenhendler E, Sigaux F, Noguera ME (2003) Varicella-zoster viral meningitis mimicking lymphoma. Leuk Lymphoma 44:1793-1795
Picard C, McCarl CA, Papolos A, Khalil S, Luthy K, Hivroz C, LeDeist F, Rieux-Laucat F, Rechavi G, Rao A et al (2009) STIM1 mutation associated with a syndrome of immunodeficiency and autoimmunity. N Engl J Med 360:1971-1980

Pourchet A, Modrek AS, Placantonakis DG, Mohr I, Wilson AC (2017) Modeling HSV-1 latency in human embryonic stem cell-derived neurons. Pathogens 6(2):24

Prader S, Felber M, Volkmer B, Truck J, Schwieger-Briel A, Theiler M, Weibel L, Hambleton S, Seipel K, Vavassori S et al (2018) Lifethreatening primary varicella zoster virus infection with hemophagocytic lymphohistiocytosis-like disease in GATA2 haploinsufficiency accompanied by expansion of double negative T-lymphocytes. Front Immunol 9:2766

Ratchford JN, Costello K, Reich DS, Calabresi PA (2012) Varicellazoster virus encephalitis and vasculopathy in a patient treated with fingolimod. Neurology 79:2002-2004

Ravell JC, Matsuda-Lennikov M, Chauvin SD, Zou J, Biancalana M, Deeb SJ, Price S, Su HC, Notarangelo G, Jiang P, Morawski A, Kanellopoulou C, Binder K, Mukherjee R, Anibal JT, Sellers B, Zheng L, He T, George AB, Pittaluga S, Powers A, Kleiner DE, Kapuria D, Ghany M, Hunsberger S, Cohen JI, Uzel G, Bergerson J, Wolfe L, Toro C, Gahl W, Folio LR, Matthews H, Angelus P, Chinn IK, Orange JS, Trujillo-Vargas CM, Franco JL, Orrego-Arango J, Gutiérrez-Hincapié S, Patel NC, Raymond K, Patiroglu T, Unal E, Karakukcu M, Day AG, Mehta P, Masutani E, de Ravin SS, Malech HL, Altan-Bonnet G, Rao VK, Mann M, Lenardo MJ (2020) Defective glycosylation and multisystem abnormalities characterize the primary immunodeficiency XMEN disease. J Clin Invest 130: $507-522$

Rodenburg EM, Vermeij FH, van den Bent MJ, Zuetenhorst JM (2017) Varicella zoster virus encephalitis in a patient with a solid carcinoma: a case report. J Neurol 264:1281-1283

Roesler J, Kofink B, Wendisch J, Heyden S, Paul D, Friedrich W, Casanova JL, Leupold W, Gahr M, Rosen-Wolff A (1999) Listeria monocytogenes and recurrent mycobacterial infections in a child with complete interferon-gamma-receptor (IFNgammaR1) deficiency: mutational analysis and evaluation of therapeutic options. Exp Hematol 27:1368-1374

Sabry A, Hauk PJ, Jing H, Su HC, Stence NV, Mirsky DM, Nagel MA, Abbott JK, Dragone LL, Armstrong-Wells J, Curtis DJ, Cohrs R, Schmid DS, Gilden D, Gelfand EW (2014) Vaccine strain varicellazoster virus-induced central nervous system vasculopathy as the presenting feature of DOCK8 deficiency. J Allergy Clin Immunol 133:1225-1227

Saitsu H, Osaka H, Sasaki M, Takanashi J, Hamada K, Yamashita A, Shibayama H, Shiina M, Kondo Y, Nishiyama K, Tsurusaki Y, Miyake N, Doi H, Ogata K, Inoue K, Matsumoto N (2011) Mutations in POLR3A and POLR3B encoding RNA polymerase III subunits cause an autosomal-recessive hypomyelinating leukoencephalopathy. Am J Hum Genet 89:644-651

Sanchez GAM, Reinhardt A, Ramsey S, Wittkowski H, Hashkes PJ, Berkun Y, Schalm S, Murias S, Dare JA, Brown D, Stone DL, Gao L, Klausmeier T, Foell D, de Jesus AA, Chapelle DC, Kim H, Dill S, Colbert RA, Failla L, Kost B, O’Brien M, Reynolds JC, Folio LR, Calvo KR, Paul SM, Weir N, Brofferio A, Soldatos A, Biancotto A, Cowen EW, Digiovanna JJ, Gadina M, Lipton AJ, Hadigan C, Holland SM, Fontana J, Alawad AS, Brown RJ, Rother KI, Heller T, Brooks KM, Kumar P, Brooks SR, Waldman M, Singh HK, Nickeleit V, Silk M, Prakash A, Janes JM, Ozen S, Wakim PG, Brogan PA, Macias WL, Goldbach-Mansky R (2018) JAK $1 / 2$ inhibition with baricitinib in the treatment of autoinflammatory interferonopathies. J Clin Invest 128:3041-3052

Sandborn WJ, Su C, Panes J (2017) Tofacitinib as induction and maintenance therapy for ulcerative colitis. N Engl J Med 377:496-497 
Schabitz WR, Rogalewski A, Hagemeister C, Bien CG (2014) VZV brainstem encephalitis triggers NMDA receptor immunoreaction. Neurology 83:2309-2311

Schimpff S, Serpick A, Stoler B, Rumack B, Mellin H, Joseph JM, Block J (1972) Varicella-zoster infection in patients with cancer. Ann Intern Med 76:241-254

Schober T, Magg T, Laschinger M, Rohlfs M, Linhares ND, Puchalka J, Weisser T, Fehlner K, Mautner J, Walz C, Hussein K, Jaeger G, Kammer B, Schmid I, Bahia M, Pena SD, Behrends U, Belohradsky BH, Klein C, Hauck F (2017) A human immunodeficiency syndrome caused by mutations in CARMIL2. Nat Commun 8:14209

Sen N, Sung P, Panda A, Arvin AM (2018) Distinctive roles for type I and type II interferons and interferon regulatory factors in the host cell defense against varicella-zoster virus. J Virol 12;92(21): e01151-18

Serac G, Tubach F, Mariette X, Salmon-Ceron D, Ravaud P, Liote F, Laharie D, Ziza JM, Marguerie L, Bonnet C et al (2012) Risk of herpes zoster in patients receiving anti-TNF-alpha in the prospective French RATIO registry. J Invest Dermatol 132:726-729

Sogaard OS, Lohse N, Ostergaard L, Kronborg G, Roge B, Gerstoft J, Sorensen HT, Obel N (2012) Morbidity and risk of subsequent diagnosis of HIV: a population based case control study identifying indicator diseases for HIV infection. PLoS One 7:e32538

Sokal JE, Firat D (1965) Varicella-zoster infection in Hodgkin's disease: clinical and epidemiological aspects. Am J Med 39:452-463

Spinner MA, Sanchez LA, Hsu AP, Shaw PA, Zerbe CS, Calvo KR, Arthur DC, Gu W, Gould CM, Brewer CC, Cowen EW, Freeman AF, Olivier KN, Uzel G, Zelazny AM, Daub JR, Spalding CD, Claypool RJ, Giri NK, Alter BP, Mace EM, Orange JS, CuellarRodriguez J, Hickstein DD, Holland SM (2014) GATA2 deficiency: a protean disorder of hematopoiesis, lymphatics, and immunity. Blood 123:809-821

Strangfeld A, Listing J, Herzer P, Liebhaber A, Rockwitz K, Richter C, Zink A (2009) Risk of herpes zoster in patients with rheumatoid arthritis treated with anti-TNF-alpha agents. JAMA 301:737-744

Tattevin P, Schortgen F, de Broucker T, Dautheville S, Wolff M (2001) Varicella-zoster virus limbic encephalitis in an immunocompromised patient. Scand J Infect Dis 33:786-788

Teo SY, Raha D, Warren D, Hassan A, Monteiro E (2014) Central nervous system-immune reconstitution inflammatory syndrome presenting as varicella zoster virus-mediated vasculitis causing stroke. Int J STD AIDS 25:683-685

Thomas SL, Hall AJ (2004) What does epidemiology tell us about risk factors for herpes zoster? Lancet Infect Dis 4:26-33

Thomas SL, Wheeler JG, Hall AJ (2002) Contacts with varicella or with children and protection against herpes zoster in adults: a case-control study. Lancet 360:678-682

Tomkins A, Babu C, Herwadkar A, Siripurapu R, McKee D (2018) Varicella zoster virus cerebral aneurysmal vasculopathy presenting in a newly-diagnosed HIV-positive patient. Int J STD AIDS 29: $1351-1353$

van Delden C, Stampf S, Hirsch HH, Manuel O, Meylan P, Cusini A, Hirzel C, Khanna N, Weisser M, Garzoni C et al (2020) Burden and timeline of infectious diseases in the first year after solid organ transplantation in the Swiss transplant cohort study. Clin Infect Dis. https://doi.org/10.1093/cid/ciz1113

van der Werff ten Bosch JE, Kollen WJ, Ball LM, Brinkman DM, Vossen AC, Lankester AC, Egeler RM, Bredius RG (2009) Atypical varicella zoster infection associated with hemophagocytic lymphohistiocytosis. Pediatr Blood Cancer 53:226-228
Venkataramana A, Pardo CA, McArthur JC, Kerr DA, Irani DN, Griffin JW, Burger P, Reich DS, Calabresi PA, Nath A (2006) Immune reconstitution inflammatory syndrome in the CNS of HIV-infected patients. Neurology 67:383-388

Wareham DW, Breuer J (2007) Herpes zoster. BMJ 334:1211-1215

Whitley RJ, Gnann JW Jr (1995) Herpes zoster in patients with human immunodeficiency virus infection-an ever-expanding spectrum of disease. Clin Infect Dis 21:989-990

Williamson EM, Berger JR (2015) Central nervous system infections with immunomodulatory therapies. Continuum (Minneap Minn) 21:1577-1598

Winthrop KL, Park SH, Gul A, Cardiel MH, Gomez-Reino JJ, Tanaka Y, Kwok K, Lukic T, Mortensen E, Ponce de Leon D, Riese R, Valdez $H$ (2016) Tuberculosis and other opportunistic infections in tofacitinib-treated patients with rheumatoid arthritis. Ann Rheum Dis 75:1133-1138

Wolfe F, Michaud K, Chakravarty EF (2006) Rates and predictors of herpes zoster in patients with rheumatoid arthritis and noninflammatory musculoskeletal disorders. Rheumatology (Oxford) 45:1370-1375

Wood JN, Boorman JP, Okuse K, Baker MD (2004) Voltage-gated sodium channels and pain pathways. J.Neurobiol 61:55-71

Wong KK, Hirsch MS (1984) Herpes virus infections in patients with neoplastic disease. Diagnosis and therapy. Am J Med 76:464-478

Yee CS, Massaad MJ, Bainter W, Ohsumi TK, Foger N, Chan AC, Akarsu NA, Aytekin C, Ayvaz DC, Tezcan I et al (2016) Recurrent viral infections associated with a homozygous CORO1A mutation that disrupts oligomerization and cytoskeletal association. J Allergy Clin Immunol 137(879-888):e872

Yeung J, Cauquil C, Saliou G, Nasser G, Rostomashvili S, Adams D, Theaudin M (2013) Varicella-zoster virus acute myelitis in a patient with MS treated with natalizumab. Neurology 80:1812-1813

Zerboni L, Arvin A (2015) Neuronal subtype and satellite cell tropism are determinants of varicella-zoster virus virulence in human dorsal root ganglia xenografts in vivo. PLoS Pathog 11:e1004989

Zerboni L, Sen N, Oliver SL, Arvin AM (2014) Molecular mechanisms of varicella zoster virus pathogenesis. Nat Rev Microbiol 12:197210

Zhang N, Wilkinson S, Riaz M, Ostor AJ, Nisar MK (2012) Does methotrexate increase the risk of varicella or herpes zoster infection in patients with rheumatoid arthritis? A systematic literature review. Clin Exp Rheumatol 30:962-971

Zhang Q, Davis JC, Lamborn IT, Freeman AF, Jing H, Favreau AJ, Matthews HF, Davis J, Turner ML, Uzel G, Holland SM, Su HC (2009) Combined immunodeficiency associated with DOCK8 mutations. N Engl J Med 361:2046-2055

Zhang SY, Jouanguy E, Ugolini S, Smahi A, Elain G, Romero P, Segal D, Sancho-Shimizu V, Lorenzo L, Puel A, Picard C, Chapgier A, Plancoulaine S, Titeux M, Cognet C, von Bernuth $\mathrm{H}, \mathrm{Ku} \mathrm{CL}$, Casrouge A, Zhang XX, Barreiro L, Leonard J, Hamilton C, Lebon P, Heron B, Vallee L, Quintana-Murci L, Hovnanian A, Rozenberg F, Vivier E, Geissmann F, Tardieu M, Abel L, Casanova JL (2007) TLR3 deficiency in patients with herpes simplex encephalitis. Science 317:1522-1527

Publisher's note Springer Nature remains neutral with regard to jurisdictional claims in published maps and institutional affiliations. 